\title{
Intertemporal Trade between Developed and Develop- ing Nations: A Model of Host-Donor Tensions
}

\author{
Walter Enders and Raj Roy*
}

\begin{abstract}
Using a two-country overlapping generations model, we analyze some of the tensions between developed and developing nations regarding international capital movements. The nature of the model is such that optimizing agents in the South have a high rate of time preference. Otherwise, the North and the South are alike in all resepects. The differential rate of time preference means that the South is likely to have a relatively low capital/labor ratio, wage rate, and level of per capita income but a relatively high interest rate in autarkic equilibrium. The introduction of international capital flows (intertemporal trade) will be welfare reducing for the current generation in the South even though it may increase the next generation's (and steady state) utility. We discuss the international conflicts which arise with international capital movements and the intergenerational conflicts which arise within each nation.
\end{abstract}

\section{I . Introduction}

Host nations typically express serious concerns about direct foreign investment. United States policymakers are wary of Japanese direct investment in the U.S. while strongly objecting to Canadian barriers to direct investment. In the same vein, one key issue in the NIEO dialogue centers on the appropriate policies

* The authors are Professors of Economics at Iowa State University and the University of Toledo, respectively. 
towards multinational firms. A goal of this paper is to explain the host's disinclination towards direct foreign investment. In the economic development literature, objections to direct investment center around the political influence of the multinational, market failures, myopic agents, and/or government induced distortions. The nature of our argument is quite different in that we assume all agents are forward looking optimizers operating in perfectly competitive markets. It is not our aim to dispute the importance of market failures as obstacles to economic development. Instead, the tradition within the economics profession has been to analyze problems of many varieties within the optimizing/competitive framework. Many fruitful insights have been gleaned from this methodology even though non -competitive elements impinge on the problem at hand. Our objective is to follow in this tradition with regard to international capital flows between the North and the South.

There is a vast literature concerning the determinants of international capital movements within an optimizing framework; this general methodology is contained in papers by Anderson (1989), Eaton (1988), Galor (1986), Ruffin and Yoon $(1990)$, and Siebert $(1985,1989)$ among others. Specifically, it is our intent to draw out some of the implications of the Diamond (1965)-Buiter (1981) two-conutry/overlapping-generations model in order to analyze host/donor issues regarding international capital mobility. The nature of the model is such that agents in one nation (the South) have a relatively high rate of time preference. Otherwise, the North and the South are alike in all regards; both have the same aggregate production function, intra-period utility function, and rate of population growth. To preview our results, the differential rate of time preference means that the South is likely to have a relatively low capital/labor ratio, wage rate, and level of per capita income but a relatively high interest rate in autarkic equilibrium. The introduction of international capital flows will be welfare reducing for the current generation in the South even though it can increase the next generation's (and steady state) utility. Residents in the North, on the other hand, will benefit from the capital flow. Since, real interest rate equalization places the world economy on its production possibilities frontier, the North must gain more than the South loses.

A side-payment (i.e., a transfer) will be necessary to induce the potential host to accept the direct investment. A major aim of the paper is to show that 
the transfer will be necessary each and every period - the young generation in the South will always have the incentive to kick the foreigners out unless an additional side-payment is forthcoming. Thus, there will be a sustained, although indeterminate, flow of side-payments into the South. We also show that the welfare of the young of any particular generation in the South is always positively related to the size of the side-payment. In the long-run, however, welfare of the South (and the North) may be negatively related to the size of the side-payment. The non-uniqueness of the side-payment gives rise to a number of interesting issues concerning the size and distribution of the payment.

\section{The Model}

The model we employ is a simple extension of the Diamond (1965)-Buiter (1981) model which allows us to consider international transfers. There are two countries, the South and the North, which are identical in all respects except that residents in the South have a high rate of time preference. The institutional structure is such that an agent born in the South at the beginning of any period $t$ lives for two periods. During the first period of life, the individual sells one unit of labor and receives wage income $w_{1}$. Also during this first period, the individual receives a side-payment $\left(s_{t}\right)$ from residents of the North. ${ }^{1}$ At this point, we do not motivate the need for the transfer. As we show, if $s_{t}=0$, residents in the South will choose to expel foreign capital (or remain in autarky).

During the first period of life, the agent must decide how much to save and how much to consume. The individual leaves no bequests and consumption/ saving decisions are made under conditions of perfect foresight. Saving in $t$ earns the real market interest rate $r_{t+1}$; principle plus interest are used to finance second period consumption. After consumption in the second period of life, the agent leaves the economic system and a new generation is born. Population grows at the constant rate $n$.

1. To consider the case in which the transfer is received during the second period of life, simply let $s_{t}$ represent the present discounted value of the transfer. Mathematically, no other alterations of the model are needed. However, the political economy may differ since the North in $t+1$ can threaten to renege on its period $t$ promise to pay the transfer. 
Thus, individuals of the South born during period $t$ face the following optimization problem:

$$
\begin{array}{ll}
\max & v\left(c_{t}{ }^{l}\right)+\frac{v\left(c_{t}^{2}\right)}{1+\rho} ; v^{\prime}>0 ; v^{\prime \prime}<0 ; \rho>0 \\
\text { s.t. } & w_{t}+s_{t}-c_{t}{ }^{l} \leq a_{t} \\
& a_{t}\left(1+r_{t+1}\right) \geq c_{t}^{2} \\
& c_{t}{ }^{l}, c_{t}{ }^{2} \geq 0
\end{array}
$$

where: $c_{j}^{i}=$ consumption of an individual born in period $j$ during the $i$-th period of life; $a_{t}=$ real saving in period $t ; r_{t+1}=$ real interest rate on saving between $t$ and $t+1 ; \rho=$ rate of time preference. As Buiter (1981) notes, although the utility function in equation (1) is quite specific, it has the virtue of allowing us to unambiguously define international differences in the pure rate of time preference.

Assuming an interior solution to the optimization problem, the demand funciton by the young during their first period of life is:

$$
c_{t}^{l}=c\left(w_{t}+s_{t}, r_{t+1} ; \rho\right)
$$

It is easily verified that an increase in full income $\left(w_{t}+s_{l}\right)$ increases consumption demand by less than the increase in income; a portion of any additional income is saved in order to finance additional second-period consumption. The effect of an interest rate change is ambiguous; since all agents are savers, a positive income effect tends to offset the negative substitution effect. In the remainder of the paper, we assume that the substitution effect always dominates the income effect; thus, first-period consumption is assumed to be inversely related to the interest rate. Finally, first-period consumption is positively related to $\rho$; those who heavily discount future consumption will spend relatively large amounts in the first period of life. Given that first-period consumption is inversely related to the interest rate, the signs of the partial derivatives of equation (5) are 
give by $:^{2}$

$$
0<c_{w}<1 ; c_{r} \leqq 0 ; c_{\rho}>0
$$

where: the notation $c_{x}$ is used to denote the partial derivative of the function $c$ with respect to the argument $x$.

In order to highlight the issue of international capital movements, it is assumed that there is a single homogeneous good. Thus, all trade is intertemporal trade. Production occurs under competitive conditions so that factors are paid their marginal products. Equilibrium in the factor market entails:

$$
\begin{aligned}
& y_{t}=f\left(k_{t}\right) ; f^{\prime}>0 ; f^{\prime \prime}<0 ; f^{\prime}(0)=\infty ; f^{\prime}(\infty)=0 \\
& w_{t}=f\left(k_{t}\right)-k_{t} f^{\prime}\left(k_{t}\right) \\
& r_{t}=f^{\prime}\left(k_{t}\right)
\end{aligned}
$$

where: $y_{t}=$ real per capita output and $k_{t}=$ capital/labor ratio.

The nature of the capital formation process is such that it takes one period to transform savings (=investment) into capital; thus, the capital stock in $t$ is the amount invested during $t-1$. Note that this assumption is formally equivalent to assuming that a unit of capital installed in $t-1$ does not bear output until period $t$.

If there is not international capital mobility in $t$, the capital stock in $t+1$ is: ${ }^{3}$

$$
k_{t+1}(1+n)=w_{t}-c_{t}^{1}
$$

2. In the Appendix, we demonstrate:

$$
\begin{aligned}
& c_{w} \equiv\left(1+r_{t+1}\right)^{2} v_{22} / \Omega ; 0<c_{w}<1 . \\
& c_{r} \equiv\left[v_{2}+c_{l}^{2}\left(1+r_{t+1}\right)^{2} v_{22}\right] / \Omega \\
& c_{p} \equiv-v_{1} / \Omega ; c_{w}>0 . \\
& \text { where: } \Omega=(1+\rho) v_{11}+\left(1+r_{t+1}\right)^{2} v_{22}<0 .
\end{aligned}
$$

3. Let $L_{t}$ represent the number of individuals born at $t$ and $K_{t}$ represent the aggregate capital stock at $t$. Aggregate saving in $t$ is: $\left(w_{t}-c_{t}^{l}\right) L_{t}=K_{t+i}$. The capital/labor ratio in $t+1$ is $k_{t+1}$ $=\left(w_{t}-c_{t}^{\prime}\right) L_{t} / L_{t+1}$. Since the rate of population growth $n=L_{t+1} / L_{t}-1$, equation (10) follows directly. 
International capital movements have the same timing effects as the domestic installation of capital. A unit of foreign capital installed in the host country in $t-1$ does not bear output until time period $t$. Thus, if capital is mobile in $t$, interest rate equalization entails a common capital/labor ratio - hence common interest rates and wage rates - for period $t+1$. With capital mobility in $t$, equation (10) is replaced by:

$$
2(1+n) k_{t+l}=w_{t}-c_{t}^{l}+w_{t}^{*}-c_{t}^{*}
$$

where: * denotes the North's counterpart of the South's variable.

Notice that $w_{t}$ need not equal $w_{t}^{*}$; in period $t$, wage rates would be equal only if there had been capital mobility in period $t-1$ or if by some coincidence out-of-steady-state capital/labor ratios happened to be equal in the two nations.

Buiter argues that it is likely that the country with the high rate of time preference will be the nation with the low capital/labor ratio and high interest rate (and thus, the host). He proves the following propositions comparing autarkic equilibria in the two nations: ${ }^{4}$

Proposition 1: If the two nations have the same initial capital/labor ratio $\left(k_{0}\right)$, the country with the high rate of time preference will have a lower capital/ labor ratio than the other nation in all subsequent periods. Moreover, if the high time-preference nation begins with a greater capital/labor ratio than the other nation, the time paths of the capital/labor ratios will eventually cross so that the high time-preference nation eventually has the lower capital/labor ratio.

Proposition 2: Let $k_{t}^{s}$ and $k_{t}^{n}$ be the autarkic capital/labor ratios in the South and North, respectively. If the autarkic capital/labor ratios are such that $k_{i}^{s}<$ $k_{t}^{n}$, then the common capital/labor ratio under capital mobility for $t+1$ \{i.e., $\left.k_{t+l}\right\}$ is between the capital/labor ratios that would prevail if autarky were

4. The formal proofs are available in Buiter (1981). Note that the stability condition in the case of portfolio autarky is:

$$
\left|\left(c_{w}-1\right) k f^{\prime \prime}\left[1+n+c, f^{\prime \prime}\right]^{-1}\right|<1
$$

and for the case of capital mobility:

$$
\left|\left(c_{w}+c_{w}^{*}-2\right) k f^{\prime \prime}\left[2(1+n)+\left(c_{r}+c_{r}^{*}\right) f^{*}\right]^{-1}\right|<1
$$


maintained: $k_{t+1}{ }^{s}<k_{t+1}<k_{t+1} 1^{n}$. Alternatively, $r_{t+1}{ }^{n}<r_{t+1}<r_{t+1}$.

Propositions (1) and (2) provide interesting insights into the nature of the comparative autarkic equilibria. The nation with the relatively high (low) rate of time preference will have many characteristics of the South (the North). Each generation in the nation with the high rate of time preference will save relatively little; it is likely to have the relatively low capital/labor ratio. Assuming this condition holds (i.e., $k_{t}^{s}<k_{t}^{n}$ ), the South will have a relatively low level of per capita income (since $f^{\prime}<0$ ) and a relatively high real rate of interset (since $f^{\prime \prime}<$ 0 ). Moreover, wages in the South will be below those of the North; from equation (7), $d w_{\imath} / d k_{t}=-k_{\iota} f^{\prime \prime}>0$. If capital movements are allowed in $t$, real capital will flow from the North to the South in search of high real interest rates. The equilibrium levels of the capital/labor ratio and real interest rate (i.e., $k_{t+1}$ and $r_{t+1}$ ) will be between those which would have prevailed had autarky been maintained. In the remainder of the paper, we will continue to assume that the South has the relatively high rate of time preference $\left(\rho>\rho^{*}\right)$ and that the autarkic capital/labor in the South is less than in the North.

\section{The Effects of Capital Movements}

Proposition (2) demonstrates that the introduction of capital mobility will increase the capital stock in the host nation and decrease the capital stock in the donor (as compared to remaining in autarky). Thus, as is often argued, direct foreign investment will raise production and wages and decrease interest rates in the host nation. It is inappropriate, however, to conclude that the wage and produciton gains are welfare increasing for all members of all generations. As we formally demonstrate in the Appendix, for any given value of $k_{t}$, the utility of an agent born at $t$ is positively related to $r_{t+l}$. Intuitively, an increase in $r_{t+t}$ raises the return from any given amount of saving. Since the newly born generation in $t$ saves in order to finance $t+1$ consumption, their utility is positively related to the interest rate. ${ }^{5}$ The key point (see Proposition 2) is that capital mobility in

5. Notice that wages in $t$, however, are unaffected by the capital flow in period $t$; from equation (8), $w_{t}$ is determined by $k_{t}$. Hence, saving in period $t-1$, but not $t$, affects wages in $t$. 
$t$ causes the interest rate to rise in the donor nation and to fall in the host. Thus, the introduciton of capital mobility in period $t$ is unambiguously welfare reducing for the young generation in the host nation and unambiguously welfare increasing for the young generation in the donor nation. Notice that utility of the old generation in $t$ is unaffected by changes in $r_{t+1}$; the consumption of this generation in period $t$ (i.e., $c_{t-1}^{2}$ ) is financed from saving in period $t-1$.

Indentifying the nation with the high rate of time preference as the South means that the introduction of capital mobility casuses welfare in the South to decline and welfare in the North to rise for those alive during period $t$. Buiter (1981) argues that the South will not allow capital mobility unless there is a side -payment or transfer at $t$ from the young in the North to the young in the South. That such a transfer is feasible is clear; capital mobility during period $t$ equalizes the marginal productivities of capital across nations. Since capital mobility is $\mathrm{Pa}$ reto-efficient, the gainers - the young in the North - must be able to compensate the losers - the young in the South. As we discuss in Section V, there are inefficient means of taxing the capital inflow from the North; per-unit taxes and interest rate taxes are but two examples. The efficient tax is a lump-sum or entry tax which does not induce a gap between interest rates of the two nations. With an efficient tax, the North pays the sum $s_{t}$ multiplied by the number of workers in the South; in return, the South allows an unrestricted flow of capital during period $t$.

What Buiter (1981) does not discuss is that the North must make a sustained flow of side-payments to the South. The need for a continual transfer can be demonstrated from the following propositions:

Proposition 3: For any given value of $k_{t}$, a return to portfolio autarky will be associated with a lower value of the South's capital stock than if capital mobility were to be maintained. For the North, a return to autarky will be associated with a higher value of the capital stock than if capital mobility were to be maintained. The required demonstration is:

$$
\begin{aligned}
& k_{t+1}{ }^{s}<k_{t+1}<k_{t+1}{ }^{n} \text { or: } \\
& r_{t+1}{ }^{n}<r_{t+1}<r_{t+1}{ }^{s}
\end{aligned}
$$

Proposition 4: For any given value of $k_{l}$, the welfare of an individual born at $t$ is positively related to $r_{t+l}$ and to the size of the side-payment he/she receives. 
Formally, Proposition (3) is equivalent to Proposition (2) above; the proof is provided in the Appendix and following Proposition (6). These two propositions hold for any arbitrary values of $k_{t}$ and $k_{l}^{*}$; not just the autarkic values of the capital stocks. Thus, even from a regime of capital mobility, Propositions (3) and (4) establish the need for a sustained transfer to the South. Each young generation in the South will press for a return to autarky; the rise in the domestic interest rate will be beneficial to members of the young generation in the South and will not affect the welfare of the old. In each period $t$, a time-consistent solution for the South is to kick out foreign capital unless an additional sidepayment is forthcoming. At the same time, members of the young generation in the North will experience a welfare decline if there is a suspension of capital mobility. (Recall that members of the old generation in the North during period $t$ are unaffected by capital movements in period $t$ ). Thus, for every period $t$, the North is willing to pay a transfer in order to maintain (or restore) capital mobility. Moreover, the North is always able to make a transfer of sufficient size transfer that induces the South to allow capital movements. Given that capital mobility is Pareto-efficient, the gains to the North from capital movements must exceed the losses to the South. Thus, a transfer must be made each and every period; the South will always demand a side-payment from the North and residents of the North are always willing and able to make such a payment. Of course, generations subsequent to those born in period $t$ will be affected by the existence of capital mobility in $t$. However, in the absence of forward-looking governments, it is not possible for the preferences of these future generations to be expressed during period $t$.

\section{General Equilibrium Effects of the Transfer}

Having demonstrated the need for a continual stream of side-payments, it is interesting to consider the effects on both the North and the South. Let $u^{a}$ be the reduced form level of utility received by agents born in the South during period $t$ if autarky prevails in $t$. Let $u^{c}$ denote reduced form utility (with a transfer) if capital mobility prevails in $t$. Residents of the South will allow capital mobility if they receive a transfer of sufficient magnitude such that: 


$$
\left.u^{c}\left(w_{t}+s_{t}, r_{t+1}\right)>u^{a}\left(w_{t}, r_{t+l}\right)^{2}\right) ; s_{t}>0
$$

Similarly, residents in the North will be willing to make any transfer such that:

$$
u^{* c}\left(w_{t}^{*}-s_{t}, r_{t+1}\right)>u^{* a}\left(w_{t}^{*}, r_{t+1}^{n}\right)
$$

Without modeling the bargaining game between the North and the South, the magnitude of the transfer which will result from the bargaining process is indeterminate. There is a range of $s_{t}$ values for which the inequalities (11) and (12) are simultaneously satisfied. Given that the North makes a transfer of sufficient size to induce the South to allow capital mobility, it is possible to ascertain the consequences of changes in the size of the transfer.

\section{A. The Transfer and the Capital Stock}

The consequences of a marginal increase in the size of the transfer on the capital stock and interest rates are given by Proposition (5).

Proposition 5: An increase in the magnitude of the transfer in $t$ has an ambiguous effect on the capital stock in $t+1$. Under the presumption that the marginal propensity to consume in the South exceeds that of the North, the capital stock in $t+1$ and in each subsequent period is inversely related to the size of the transfer. ${ }^{6}$

Intuitively, each unit of resoruces transferred increases consumption in the South by $c_{w}$ but decreases consumption in the North by $c_{w}{ }^{*}$. If the former exceeds the latter, overall consumption increases and capital formation declines.

6. The marginal propensity to consume in the South $\left(c_{w}\right)$ will exceed that in the North $\left(c_{w}{ }^{*}\right)$ if the marginal propensity to consume out of wage income is increasing in the rate of time preference (i.e., if $d c_{w} / d \rho>0$ ). Note that this is the case with a wide variety of utility functions. Using a homothetic utility function, for example, $v_{1} / v_{2}$ is independent of the level of consumption. For this class of utility functions, $c_{t}{ }_{t}$ is proportional to $w_{t}$ so that the marginal propensity to consume is constant. Hence, the propensity to consume depends only on $r_{t+1}$ and $\rho$. For any given common value of the interest rate, the demonstration that $c_{\rho}>0$ directly implies $d c_{w} / d \rho>0$. 
Proof: With capital mobility, the capital stock in $t+1$ is given by equation $\left(10^{\prime}\right)$. Combining $\left(10^{\prime}\right)$ and $(5)$ :

$2(1+n) k_{t+1}=w_{t}-c\left(w_{t}+s_{t}, r_{t+1}\right)+w_{t}^{*}-c^{*}\left(w_{t}^{*}-s_{t}, r_{t+1}\right)$.

Since $w_{t}$ and $w_{t}^{*}$ are predetermined and independent of the size of the transfer in $t$ :

$2(1+n) d k_{t+1}=-c_{w} d s_{t}-c_{r} f^{\prime \prime} d k_{t+1}+c_{w}^{*} d s_{t}-c_{r}^{*} f^{\prime \prime} d k_{t+1}$

Thus:

$$
d k_{t+1} / d s_{\ell}=\left(c_{w}^{*}-c_{w}\right) /\left\{2(1+n)+c_{r} f^{\prime \prime}+c_{r}^{*} f^{\prime \prime}\right\}
$$

Thus, $d k_{t+1} / d s_{l}<0$ as $f^{\prime \prime}<0 ; c_{r}<0 ; c_{r}^{*}<0$; and $c_{w}{ }^{*}<c_{w}$.

Since the dynamic system has a single characteristic root, a decline in $k_{t+1}$ directly implies a reduction in $k_{t+2}$ and in all subsequent values of the capital stock. ${ }^{7}$ The effect of the transfer on the steady state value of the capital stock also depends on the difference between the marginal propensities to consume. Let the steady-state value of the transfer be denoted by the constant $s$ and let $k_{t}=$ $k_{t+1}=k_{t+2}=\cdots=k$. The steady state version of equation $\left(10^{\prime}\right)$ is:

$$
2(1+n) k=w(k)-c\{w(k)+s, r(k)\}+w^{*}(k)-c^{*}\{w(k)-s, r(k)\}
$$

where: a variable without a subscript denotes the steady-state value of that variable.

Taking the total differential of equation (14):

$$
\frac{d k}{d s}=\frac{c_{w}^{*}-c_{w}}{2(1+n)+\left(2-c_{w}-c_{w}^{*}\right) k f^{\prime \prime}+\left(c_{r}+c_{r}^{*}\right) f^{\prime \prime}}
$$

7. For a formal explanation, note that equation $\left(10^{\prime}\right)$ is a first-order difference equation. If the stability condition is everywhere satisfied, the time path of the capital stock must be monotonic. 
From the stability condition, the denominator of (15) is positive. Thus, the steady-state value of the capital stock changes in the same direction as the capital stock in the short-run. Notice, that the absolute value of the steady-state change in the capital stock is larger than the short-run value (see equation (13)). To explain, consider the effects of a marginal increase in the transfer at $t$ that is to be maintained for all future periods. From equation (13), the capital stock in period $t+1$ will fall (assuming the condition that the marginal propensity to consume in the South exceeds that in the North). The generation born in $t+1$ - and all subsequent generations - will receive lower wages than if the transfer had been maintained at its original level. With lower wages, the savings and capital/labor ratios of generations $t+1$ and beyond will be diminished.

\section{B. The Transfer and Utility Levels}

From Proposition (4), an individual born in the South during $t$ will prefer that his/her transfer be increased for any given value of $r_{t+1}$. However, as just shown, if all members of generation $t$ receive a transfer, the capital stock and interest rate will change. Proposition (6) generalizes Proposition (4) in order to consider the general equilibrium effects of the transfer.

Proposition 6: For a given value of $k_{i}$, welfare of the young generation in the South at time $t$ is positively related to the size of the transfer if $c_{u}{ }^{*}<c_{w v}$. The welfare of the young generation in the North, however, is ambiguously related to the size of the transfer.

Proof: Using the results in the Appendix:

$$
\begin{aligned}
& d u(t)=\left\{v_{22}\left(1+r_{t+1}\right)^{2}\left(d w_{t}+s_{t}\right)+c_{i}^{2}\left[v_{t} v_{22}+v_{11} v_{2} /\left(1+r_{t+1}\right)\right] d r_{t+1}\right\} / \Omega \\
& \text { where } \Omega=(1+\rho) v_{11}+\left(1+r_{t+1}\right)^{2} v_{22}<0
\end{aligned}
$$

Note that $w_{t}$ is unaffected by the size of the transfer in $t$ and use the result that $d r_{1+1} / d s_{t}=f^{\prime \prime} d k_{i+1} / d s_{\text {, }}$ to obtain:

$$
d u(t) / d s_{t}=\left\{v_{22}\left(1+r_{t+1}\right)^{2}+c_{t}^{2}\left[v_{t} v_{22}+v_{11} v_{2} /\left(1+r_{t+1}\right)\right] f^{\prime \prime} d k_{t+1} / d s_{t}\right\} / \Omega
$$

Since $v_{l l}, v_{23}, f^{\prime \prime}$, and $\Omega$ are negative and $d k_{l^{+} l} / d s_{t}$ is negative if $c_{w}{ }^{*}<c_{w}$, the first portion of Proposition (6) follows directly [i.e., $d u(t) / d s_{t}<0$ ]. Since the structute of 
the North and South are identical except for the rate of time preference, the equivalence of equation (16) for the North is:

$$
d u^{*}(t)=\left\{-v_{22}^{*}\left(1+r_{t+1}\right)^{2}+c_{t}^{* 2}\left[v_{l}^{*} v_{22}^{*}+v_{I l}{ }^{*} v_{2}^{*} /\left(1+r_{t+l}\right)\right] f^{\prime \prime} d k_{t+1} / d s_{t}\right\} / \Omega^{*}
$$

Given $d k_{t+1} / d s_{t}<0, d u^{*}(t) / d s_{t}$ is ambiguous in sign.

To explain, the transfer directly increases the disposable income in the South and reduces the disposable income of the young in the North. In addition, the decline in the capital stock (given that $c_{u}{ }^{*}<c_{w}$ ) means that savings of the young in $t$ will earn a higher rate of return than otherwise. Thus, the general equilibrium effect of the transfer of the interest rate acts to increase utility of the young in both the North and the South. These two effects (i.e., the disposable income and interest rate effects) are mutually reinforcing for the South but lead to an ambiguity for the level of welfare in the North.

Although each generation in the South desires to receive the largest transfer possible, the effect of a transfer in $t$ may be to reduce the utility levels of subsequent generations. From Proposition (5), the transfer in $t$ decreases the South's capital stock in all future periods. As long as $k_{t}$ is below the golden-rule, the welfare of generations born in $t+1$ and beyond will be reduced by the transfer in $t .^{8}$ Since there is a single state variable $\left(k_{t}\right)$, welfare of all subsequent generations will be diminished by the transfer in period $t$. In the case of an inefficient competitive equilibrium in which the existing capital stock is greater than the golden-rule, the transfer in $t$ clearly enhances the welfare of future generations.

\section{Intergenerational Conflicts and Second-Best Schemes}

A key insight of the model is the need for a sustained transfer and its con-

8. As in the Solow (1956) growth model, the golden rule level of the capital stock in autarky is that given by the equality of the rate of population growth and the interest rate [i.e., $f^{\prime}=n$ ]. If $K_{t}$ and $L_{t}$ are the autarkic aggregate capital stock and labor supply for period respectively, total consumption by the old and the young at $t$ is: $L_{t} c_{t}{ }^{\prime}+L_{t-1} c_{t-1}{ }^{2}=L_{t} y_{t}\left(k_{t}\right)$ $-\left(K_{t+1}-K_{t}\right)$. Divide the right-hand-side by $L_{t}$ to obtain: $\mathrm{y}\left(k_{t}\right)-K_{t+1} / L_{t}+k_{t}$. Since $K_{t+1} / L_{t}$ $=k_{t+1}(1+n)$ and on the golden-rule path $k_{t+1}=k_{l}=\cdots=k$, maximizing steady state aggregate consumption is equivalent to maximizing $y(k)-n k$. 
tinuing source of conflict between the North and the South. Moreover, the need for a transfer has important implications for intergenerational conflicts within the South. These intergenerational conflicts and the existence of second-best transfer schemes are discussed below.

\section{A. Conflicts between Generation $t$ and Subsequent Generations}

It was shown that the optimal short-run solution for the South is to block international capital movements unless a side-payment is forthcoming from the North. In time period $t$, the old in the South are indifferent to the introduction of foreign capital while the young have the incentive to kick out the foreigners. However, this solution does not take the welfare of the future generations into account; the welfare of subsequent generations may be negatively related to the size of the transfer at $t$.

A social planner having a welfare function consisting of the utility levels of all generations' utility levels, might be willing to allow the capital inflow even if no transfer is forthcoming. From a long-run planning perspective, capital inflows to the South in $t$ can be socially beneficial even though they are detrimental to the welfare of agents born in $t$. An obvious example is one in which the autarkic capital stock in the South is below its golden rule level. In this situation, steady state welfare would rise even in the absence of transfers. The transfer, by decreasing the capital/labor ratio, pushes the economy further from the goldenrule. Certainly, the forward-looking planner might be willing to trade-off the welfare loss of those alive in $t$ for the long-run gain to the future generations. There is strong incentive for the living generations in the South to adopt institutions which prevent forward-looking behavior of the part of the planner.

\section{B. Conflicts between the Young and Old Generations at $t$}

Transactions costs and free-rider problems necessitate that representatives of the North negotiate with representatives of the South concerning the size and the distribution of the transfer payments; individual-by-individual negotiations concerning the transfer are not feasible. Once the transfer has been collected, its distribution to the young is often complicated by certain institutional practices making it illegal or impractical to directly discriminate against individuals based on age (i. e., on the generation in which they were born). Certainly, the provi- 
sion of certain government services (such as government provision of emergency medical care facilities) or public goods (such as roads and other forms of infrastructure) cannot be withheld from a particular group within society. Also, the structure of tax laws often necessitates that direct tax rebates or subsidies be made independently of an individual's age.

If the proceeds of the transfer are used to provide non-rival public goods, both the old and the young generation benefit from the transfer. As long as the old in $t$ receive any of the public good, members of that generation will benefit from international capital mobility in $t$. Intergenerational conflicts can arise since the old have a greater incentive to allow foreign capital than do the young. The situation is somewhat different if the government must provide members of both generations rival goods (such as medical care) or equal per-capita transfers. Again, the old generation will favor the introduction of foreign capital. The young, however, may be overall losers as a result of the redirection of a portion of the transfer to the elderly; the magnitude of the transfer received by the young might not be sufficient to compensate them for the reduction in the interest rate induced by the capital inflow. ${ }^{9}$ In either case, there is strong incentive for the old to press for capital movements regardless of the preferences of the young.

\section{Second-Best Transfers}

Even though Pareto-efficient, lump-sum taxes on the entry on foreign capital are not prevalent. Commonly used alternatives include per-unit taxes on the inflow of foreign capital and high average tax rates on foreigners' intersest income. Requirements that multinational firms use productive techniques with relatively high labor/capital ratios are implicit taxes on foreign capitalists. These latter forms of taxation are certainly more prevalent than the lump-sum taxes discussed above. Although Pareto-inferior to the nondistorting lump-sum transfers discussed in the text, distortionary taxes are preferable to remaining in (or returning to) portfolio autarky. It would seem that the existence such second-best

9. In this situation, it might be feasible for the government in the South to promise generation $t$ a sufficiently large share of the transfer to be received in $t+1$. If the promise is credible, generation $t$ would allow capital mobility in $t$. 
schemes are the result of breakdowns in the bargaining process. If the government of the South is unsatisfied with the negotiated size of the transfer, it could unilaterally tax foreign capital. The ability of the South to impose such a tax enables the South to threaten the North should the bargaining process prove unsatisfactory. Of course, the North also has the ability to tax the export of capital; for example, the U.S. Interest Rate Equalization Tax was aimed at discouraging U.S. direct investment abroad. In a multi-period bargaining game in which both sides have credible threats, there would be periods during which such inefficient outcomes could occur.

\section{Alternative Transfers and the GATT}

In a multi-good setting, there are gains to be had from specialization in accord with comparative advantage. It is possible that this within period gain from trade is not sufficient to offset the losses from intertemporal trade. This can explain why in the current Uruguay Round, the nations of the South have expressed reluctance to open up their markets to the products of the North. Unless the North is willing to offer concessions, the lived generations in the South may have nothing to gain by allowing free trade. At the same time, the North is pressing the South to respect intellectual property rights. The analysis suggests that a successful conclusion to the North/South dialogue in the Uruguay Round necessitates some form of side-payment to the South. All else equal, the North might want to make compensation the form of non-rival goods; members of both the old and young generations will then favor trade. Moreover, it should be understood from the outset of the negotiations that the South will always have the incentive to renegotiate the compensation package.

In light of this discussion, it is useful to compare two of the proposals intended to induce the South to allow freer trade and to respect intellectual property rights. The Generalized System of Preferences (GSP) - an exception to the Most Favored Nation Principle - represents an attempt to increase the demand for Southern products by reducing trade barriers on imports from selected developing nations. From the North's perspective, an expansion of the GSP is a second best form of transfer. The standard theory of Customs Unions suggests that a nation's selective removal of trade barriers may be welfare reducing if the effects of trade-diversion outweigh the beneficial trade-creation effects. Expanding 
the GSP may induce agents in some Northern countries to switch purchases from the low-cost producers in the North to high-cost producers in the South. Although expansion of the GSP is a second-best policy (since it entails a deadweight 1oss), the desirable feature of this proposal is that tariff rates can be readily altered should the South attempt to restrict intertemporal trade.

An alternative type of side-payment to the South entails debt-relief. The desirable aspect of this proposal is that an appropriately designed aid package would be a first-best policy in terms of resource allocation. Debt-relief can be a pure transfer which forgives a certain portion of the preexisting debt; hence, there is no dead-weight loss. The problem with simple debt-relief is that once loan principal has been reduced, the young generations in the South still have the incentive to prevent intertemporal trade. A properly designed debt-relief package would entail reductions in loan payments from the South which are contingent on access to Southern markets; attempts to eliminate intertemporal trade could be met with a return to the originally negotiated loan repayment plan. Such a debt-relief package would be first-best and induce the South to maintain intertemporal trade.

\section{Conlusions}

Using a two-country overlapping generations model, we analyzed some of the tensions between the North and the South regarding international capital movements. The nature of the model was such that optimizing agents in the South have a high rate of time preference. Otherwise, the North and the South are alike in all respects. The differential rate of time preference means that the South is likely to have a relatively low capital/labor ratio, wage rate, and level of per capita income but a relatively high interest rate in autarkic equilibrium. , The introduction of international capital flows (intertemporal trade) will be welfare reducing for the current generation in the South even though it may increase the next generation's (and steady state) utility. In order for the South for allow capital mobility, a sustained transfer from the South to the North must be made. The transfer itself will affect the general equilibrium solution of the two economies and gives rise to some important host/donor and intergenerational tensions.

Of course, the model has several important omissions. Markets in the South 
are not always perfect, agents may not be forward-looking optimizers, and there are government induced distortions. On an analytic level, the assumptions of identical production functions, identical and constant rates of population growth, two countries, two overlapping generations, and a single homogeneous good are certainly unrealistic. The model does offer some interesting insights into the development process; we hope that these insights justify the extreme assumptions.

\section{Appendix}

Let $u$ denote utility of an agent born at $t$. Considering only interior solutions, for any individual born in period $t$, the optimization problem is:

$$
\begin{aligned}
& \text { (A1) } \max u(t)=v\left(c_{t}^{\prime}\right)+\frac{v\left(c_{t}^{\prime}\right)}{1+\rho} ; v^{\prime}>0 ; v^{\prime \prime}<0 ; \rho>0 \\
& \text { (A2) s.t. } w_{t}+s_{t}=c_{t}^{\prime}+c_{i}^{\prime} /\left(1+r_{t+1}\right)
\end{aligned}
$$

Let $v_{i}$ denote $v^{\prime}\left(c_{i}^{\prime}\right)$. The first-order condition is:

$$
\text { (A3) } \frac{v_{l}\left(c_{t}^{\prime}\right)}{v_{z}\left(c_{t}^{\prime}\right)}=\frac{\left(1+r_{t+1}\right)}{1+\rho} \text { where: } c_{t}^{2} \text { is given by (A2). }
$$

The second order condition is: $v_{11}<0 ; v_{22}<0$.

Take the total differential of equations (A1), (A2), and (A3):

$$
\left[\begin{array}{ccc}
1 & 1 /\left(1+r_{t+1}\right) & 0 \\
v_{l l}(1+\rho) & -\left(1+r_{t+1}\right) v_{22} & 0 \\
v_{l} & v_{2} /(1+\rho) & -1
\end{array}\right]\left[\begin{array}{l}
d c_{l}^{\prime} \\
d c_{t}^{2} \\
d u(t)
\end{array}\right]=\left[\begin{array}{c}
d\left(w_{t}+s_{l}\right)+\frac{c_{l}^{2} d r_{t+1}}{\left(1+r_{t+1}\right)^{2}} \\
v_{2} d r_{t+1}-v_{l} d \rho \\
\frac{-v\left(c_{t}^{2}\right) d \rho}{(1+\rho)^{2}}
\end{array}\right]
$$

Define: $\Omega=(1+\rho) v_{11}+\left(1+r_{i+1}\right) v_{22}<0$

The properties of equation (5) are found directly:

$$
\begin{aligned}
& c_{w} \equiv\left(1+r_{l+1}\right)^{2} v_{22} / \Omega ; 0<c_{u}<1 \\
& c_{r} \equiv\left[v_{2}+c_{l}^{2}\left(1+r_{l+1}\right)^{2} v_{22}\right] / \Omega
\end{aligned}
$$


As $v_{2}>0$ and $v_{22}<0$ so that the sign of $c_{r}$ is ambiguous.

$\mathrm{c}_{o} \equiv-v_{1} / \Omega ; c_{u}>0$

The proposition that utility is increasing in $r_{t+l}$ is easily demonstrated:

$$
\begin{aligned}
& \mathrm{du}(t) / d\left(w_{l}+s_{l}\right)=v_{22}\left(1+r_{l+1}\right)^{2} / \Omega>0 \\
& d u(t) / d r_{t+1}=c_{l}^{2}\left[v_{l l} v_{2}+\left(1+r_{l+1}\right) v_{l} v_{22}\right] /\left[\left(1+r_{t+1}\right) \Omega\right]>0
\end{aligned}
$$

where: we have used the result $v_{2}\left(1+r_{t+1}\right)-v_{l}(1+\rho)=0$.

\section{References}

Anderson, James E. (1989), “The Optimal Borrowing Tax,” mimeo., Boston College: Boston, Mass.

Eaton, Jonathan (1988), “Foreign Owned Land," American Economic Review, 78, pp.76-88.

Buiter, Willem H. (1981), "Time Preference and International Lending and Borrowing in an Overlapping-Generations Model," Journal of Political Economy, 89, pp. 769-97.

Diamond, Peter A. (1965), "National Debt in a Neoclassical Growth Model," American Economic Review, 55, pp. 1-20.

Galor, Oded. (1986), “Time Preference and International Labor Migration,” Journal of Economic Theory, 38, pp.1-20

Ruffin, Roy J. and Young Deak Park (1990), “The Intergenerational and Welfare Effects of International Capital Movements," mimeo., University of Houston:Houston, Texas.

Sibert, Anne (1985), "Capital Accumulation and Foreign Investment Taxation," Review of Economic Studies, 52, pp. 331-45.

. (1989), “Taxing Capital in a Large, Open Economy," mimeo., University of Kansas: Manhattan, Kansas.

Solow, Robert M. (1956), "A Contribution to the Theory of Economic Growth," Ouarterly Journal of Economics, 70, pp. 65-94. 